\section{Can't and Won't}

\section{Tae-II Kim}

Department of Periodontology, Seoul National University School of Dentistry, Seoul, Korea

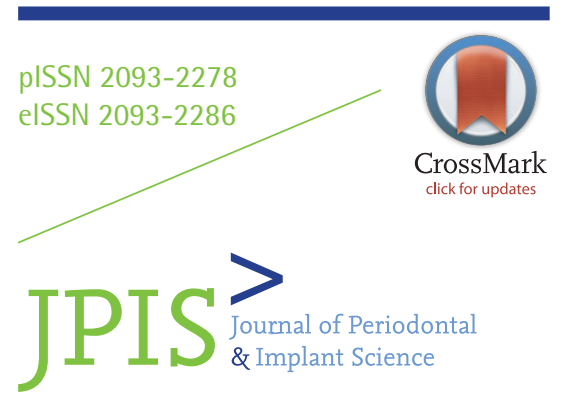

\section{Editorial}

J Periodontal Implant Sci 2014;44:49-49

http://dx.doi.org/10.5051/jpis.2014.44.2.49

Received: Apr. 3, 2014

Accepted: Apr. 3, 2014

*Correspondence:

Tae-II Kim (Editor-in-Chief)

Department of Periodontology, Seoul National University School of Dentistry, 101 Daehak-ro, Jongno-gu, Seoul 110-749, Korea

E-mail: periopf@snu.ac.kr

Tel: +82-2-2072-2642

Fax: $+82-2-744-1349$

cells obtained from this method "stimulus-triggered acquisition of pluripotency" (STAP) cells. If their method were applicable to adult human cells, their results would be a breakthrough in regenerative medicine, given that the technique provides a simpler source of stem cells than those currently available.

Since then, however, a series of concerns has been raised by researchers worldwide. Some of the figures in the published papers have been called into question, while the body text was found to be similar to a previous article. The major sticking point was the failure of other scientists to replicate their results so far. While separate investigations are underway, Riken has already issued a statement on April 1 that the Nature papers were interspersed with critical errors and called for their retraction. Dr. Ryoji Noyori, a Nobel Prize-winning chemist and Riken's president, remarked that the panel's report shows that the research misconduct occurred due to a young researcher's lack of experience and awareness of research ethics, and a lack of leadership and mutual verification among the coauthors. Meanwhile, the lead author, Dr. Haruko Obokata, has refused to retract their papers. In the meantime, Dr. Charles Vacanti, who is Obokata's former mentor at Harvard Medical School and a coauthor on those papers, has publicized his own protocol, while Dr. Kenneth Lee of the Chinese University of Hong Kong has claimed that some version of the STAP method might work.

It remains unclear whether the method for producing STAP cells will be deemed legitimate and the final decision on retraction depends on the authors and Nature. But, the situation brings to mind Lydia Davis' recent book entitled Can't and Won't. To quote the words of one of Ms. Davis' short stories, "Not Interested": "Please spare me your imagination, I'm so tired of your vivid imagination." Let us get to the truth behind the STAP papers, which should be the foremost interest of the scientific community.

\title{
ORCID
}

Tae-II Kim http://orcid.org/0000-0003-4087-8021

This is an Open Access article distributed under the terms of the Creative Commons Attribution Non-Commercial License (http://creativecommons.org/licenses/by-nc/3.0/). 